\title{
Effects of Feeding Frequency and Feeding Level on Nutrient Utilization in Heavy Preruminant Calves
}

\author{
J. J. G. C. van den Borne, ${ }^{1}$ M. W. A. Verstegen, S. J. J. Alferink, R. M. M. Giebels, and W. J. J. Gerrits \\ Animal Nutrition Group, Department of Animal Sciences, Wageningen University, 6700 AH Wageningen, The Netherlands
}

\begin{abstract}
The objective of this study was to determine the effects of feeding frequency (FF) and feeding level (FL) on protein and energy metabolism in adapted, heavy preruminant calves. It was hypothesized that an increased FF would increase protein utilization by an improved synchrony between the supply of and requirements for protein during the day when a quickly hydrolyzable protein source was used. Eighteen Holstein Friesian calves of $136 \pm 3 \mathrm{~kg}$ of body weight were assigned to $\mathrm{FF}(1,2$, or 4 meals daily) at $2 \mathrm{FL}$ ( 1.5 or 2.5 times the metabolizable energy requirements for maintenance), except for calves fed once daily (only at a low FL). Calves were individually housed in respiration chambers during 2 experimental periods of $10 \mathrm{~d}$. Whey protein was the only protein source in the diet. Neither FL nor FF affected apparent fecal nutrient digestibility. Increasing FF increased the efficiency with which digestible protein was utilized in calves. The increase was greater at a high FL $(+11 \%$ from 2 to 4 meals/d) than at a low FL ( $+5 \%$ from 2 to 4 meals/d), but no significant interaction occurred between FL and FF. An increased FF and a higher FL enhanced fat deposition. Heat production was not affected by FF, but its circadian rhythm differed considerably between FF. Activity-related heat production was not affected by FF or FL. Thus, increasing FF improved the efficiency with which protein and energy were utilized in heavy preruminant calves when a quickly hydrolyzable protein source was used.
\end{abstract}

Key words: feeding frequency, calf, energy metabolism, protein metabolism

\section{INTRODUCTION}

The growth rate and body composition of milk-fed calves can be manipulated by varying the quantity and composition of the daily feed supply. Relationships have been described for young (Diaz et al., 2001; Blome et al., 2003) and older preruminant calves (Gerrits et al., 1996).

Received September 3, 2005.

Accepted March 30, 2006.

${ }^{1}$ Corresponding author: joost.vandenborne@wur.nl
In addition to the average daily nutrient intake, the distribution of nutrient availability within a day also can be altered. Protein utilization for growth may be affected by the variation in availability of AA with time. Williams et al. (1986) found that raising the feeding frequency (FF) did not improve the utilization of protein in young milk-fed calves. The relatively low feeding level (FL), that is, 1 to 2 times the ME requirements for maintenance $\left(\mathbf{M E}_{\mathbf{m}}\right)$, may have concealed the potential effect of FF. Furthermore, the use of a clotting protein source (skimmed milk powder) may have resulted in a slow release and absorption of AA during the day and avoided high AA absorption peaks in that study. In practice, more rapidly hydrolyzable protein sources, such as vegetable and whey protein, are increasingly used in milk replacer diets and result in a more rapid and peakwise appearance of portal AA than when skimmed milk protein is fed (Verdonk et al., 1999).

Studies on the effect of FF at different FL and on the use of a rapidly hydrolyzable protein source in milkfed calves are lacking. Heavy preruminant calves utilize extra ingested protein with an extremely low efficiency $(\sim 30 \%)$ compared with young calves $(66 \%$; Blome et al., 2003; Gerrits et al., 1996). This considerable margin for improvement makes the heavy milk-fed calf a useful model for studying the effects of $\mathrm{FF}$ on protein utilization. Moreover, the mechanisms involved may be interesting for postabsorptive AA metabolism in growing ruminants, because similar protein-energy relationships exist (Gerrits et al., 1996; Schroeder et al., 2004) and technical difficulties restrict the assessment of digestible AA utilization in ruminant cattle (Titgemeyer, 2003).

The effects of FF on fat deposition are expected to be less pronounced than those on protein deposition, because the capacity for and flexibility of fat deposition are substantial. An increasing $\mathrm{FF}$ can be expected to increase physical activity and consequently activity-related heat production $\left(\mathbf{H P}_{\text {act }}\right)$. Therefore, energy retention (ER) as fat may decrease with increasing FF.

We hypothesized that increasing FF would lead to increased protein utilization in heavy preruminant calves. The effects were expected to be more pronounced at a high FL than at a low FL. Increasing the FF was expected to increase physical activity and decrease ER. 
Table 1. Experimental design and number of observations per treatment $^{1}$

\begin{tabular}{llllllll}
\hline & \multicolumn{2}{c}{ FF 1} & & \multicolumn{2}{c}{ FF 2} & & \multicolumn{2}{c}{ FF 4} \\
\cline { 2 - 3 } \cline { 6 - 7 } Period & FL low & & FL low & FL high & & FL low & FL high \\
\hline 1 & 6 & 6 & - & & 6 & - \\
2 & 6 & & - & 6 & & - & 6 \\
\hline
\end{tabular}

${ }^{1} \mathrm{FF}$ = feeding frequency; $\mathrm{FL}=$ feeding level.

The aim of the study was to assess the effects of $3 \mathrm{FF}$ at $2 \mathrm{FL}$ on protein and energy utilization in adapted, heavy preruminant calves.

\section{MATERIALS AND METHODS}

\section{Animals and Housing}

Eighteen male Holstein-Friesian calves were used in 9 trials of 2 calves of similar age ( 15 wk at start). Each trial consisted of 2 experimental periods. Both experimental periods were preceded by an adaptation period of $4 \mathrm{wk}$, which allowed the organ mass and metabolism of the calves to adapt fully to the experimental treatments.

The effects of FF $(1,2$, or 4 meals/d) were studied at $2 \mathrm{FL}\left(1.5 \times \mathrm{ME}_{\mathrm{m}}\right.$ and $\left.2.5 \times \mathrm{ME}_{\mathrm{m}}\right)$. Trials were assigned to FF. The same FF was used for both calves within a trial, because visual and (limited) auditory contact between the individually housed calves affected their physical activity and cephalic phase reflexes. Within trials, a low FL was adopted in period $1\left(1.5 \times \mathrm{ME}_{\mathrm{m}}\right)$ and a high $\mathrm{FL}$ in period $2\left(2.5 \times \mathrm{ME}_{\mathrm{m}}\right)$. In the first period, a low FL was used for all calves to permit comparison of different $\mathrm{FF}$ in a similar experimental period and at similar BW. As designed, animals at FF 1 were not fed at a high FL, because it is not feasible to feed calves at a high level in only one daily meal (Table 1). Calves at FF 1 served as controls for the effect of the experimental period, because FL was confounded with period in this study.

The adaptation period allowed calves to adapt to the experimental treatments and housing conditions. Harnesses for the fecal collection bags were attached $5 \mathrm{~d}$ before the start of the experiment. At the start of each experimental period, calves were housed individually in 1 of 2 identical, size-adjustable climatic respiration chambers set to $2.5 \times 1.5 \times 2.0 \mathrm{~m}$ (length $\times$ width $\times$ height). Within the chambers, calves were housed in metabolic cages $(1.85 \times 0.75 \mathrm{~m})$. Calves in the 2 separate chambers could see each other. Temperature was maintained at $18^{\circ} \mathrm{C}$, relative humidity was $65 \%$, and air velocity was $<0.2 \mathrm{~m} / \mathrm{s}$. Calves were exposed to $13.5 \mathrm{~h}$ of light (0000 to $0030 \mathrm{~h}$ and 0530 to $1830 \mathrm{~h} ; 50 \mathrm{~lx})$ and $10.5 \mathrm{~h}$ of darkness $(6 \mathrm{~lx})$. The experiment was approved by the Ethical Committee of Wageningen University.
Table 2. Ingredient composition and analyzed nutrient composition of the experimental diet

\begin{tabular}{lr}
\hline Item & Amount \\
\hline Ingredient, g/kg & \\
Whey & 372.9 \\
Whey protein concentrate & 360.0 \\
Delactosed whey & 70.0 \\
Soybean oil & 144.0 \\
Coconut oil & 36.0 \\
DL-Met & 1.32 \\
Monopotassium phosphate & 2.32 \\
Calcium carbonate & 6.60 \\
Magnesium oxide & 0.84 \\
Vitamin and mineral premix ${ }^{1}$ & 6.00 \\
Nutrient, ${ }^{2}$ g/kg of DM & \\
DM, g/kg & 978.0 \\
Crude ash & 73.1 \\
CP, N $\times 6.25$ & 190.5 \\
Crude fat & 195.8 \\
Lactose & 470.3 \\
Gross energy, MJ/kg & 20.6 \\
Lys & 16.2 \\
Met & 5.0 \\
Cys & 5.0 \\
Thr & 13.2 \\
Trp & 3.1 \\
Ile &
\end{tabular}

${ }^{1}$ Provided per kilogram of the experimental diet: calcium, $7.8 \mathrm{~g}$; phosphorus, $6.5 \mathrm{~g}$; magnesium, $1.4 \mathrm{~g}$; vitamin A, 25,026 IU; vitamin $\mathrm{D}_{3}, 2,000 \mathrm{IU}$; vitamin E, $80 \mathrm{mg}$; vitamin C, $130 \mathrm{mg}$; zinc, $84 \mathrm{mg}$; copper, $9 \mathrm{mg}$; iron, $48 \mathrm{mg}$; manganese, $15 \mathrm{mg}$; selenium, $0.1 \mathrm{mg}$; cobalt, $1.9 \mathrm{mg}$.

${ }^{2}$ Analyzed content, unless indicated otherwise.

${ }^{3}$ Calculated content.

\section{Diets and Feeding}

Calves were fed according to their metabolic BW $\left(\mathrm{kg}^{0.75}\right)$, adjusted daily for a projected average daily gain of $500 \mathrm{~g} / \mathrm{g}$ at the low FL and $1,500 \mathrm{~g} / \mathrm{g}$ at the high FL. The $\mathrm{ME}_{\mathrm{m}}$ was assumed to be $460 \mathrm{~kJ} /\left(\mathrm{kg}^{0.75} \cdot \mathrm{d}\right)$, based on estimations for $\mathrm{ME}_{\mathrm{m}}$ in heavy preruminant calves by Gerrits et al. [1996; 447 to $485 \mathrm{~kJ} /\left(\mathrm{kg}^{0.75} \cdot \mathrm{d}\right)$ ], and Van Es et al. [1967; $\left.448 \mathrm{~kJ} /\left(\mathrm{kg}^{0.75} \cdot \mathrm{d}\right)\right]$. The ingredient and analyzed nutrient composition of the experimental milk replacer is shown in Table 2. Whey was used as the only protein source because it is a rapidly hydrolyzable protein source that can be included at high levels in milk replacer diets. Milk replacer was reconstituted with water $(140 \mathrm{~g} / \mathrm{L})$ and supplied in a bucket at a temperature of about $40^{\circ} \mathrm{C}$. Roughage was not supplied. Feeding times were 0000 (FF 2 and 4), 0600 (FF 4), 1200 (FF 1, 2, and 4), and $1800 \mathrm{~h}$ (FF 4). Additionally, calves at FF 1 were supplied with $3 \mathrm{~L}$ of warm water $\left(40^{\circ} \mathrm{C}\right)$ at 0600 and $1800 \mathrm{~h}$ to prevent dehydration. Calves were allowed 15 min to consume the meal.

\section{Measurements}

Gas exchange was measured in 6-min intervals by measuring the exchange of oxygen, carbon dioxide, and 
methane as described by Verstegen et al. (1987). The posture of calves was measured every minute by infrared beam interruption and expressed as lying (i.e., lying during the complete 6-min interval) or nonlying (i.e., standing during at least 1 min of the 6 -min interval). Physical activity was recorded with a radar Doppler device according to the method described by Wenk and Van Es (1976).

Calves were weighed before and after each balance period. Feces were collected quantitatively in plastic bags that were harnessed to the calves. They were collected twice daily and stored at $-20^{\circ} \mathrm{C}$ pending analyses. Urine was collected in a pit containing 500 (low FL) or $750 \mathrm{~mL}$ (high FL) of $4.5 \mathrm{M}$ sulfuric acid. Aerial $\mathrm{NH}_{3}$ and $\mathrm{NH}_{4}{ }^{+}$in water that condensed on the heat exchanger were also collected quantitatively (Verstegen et al., 1987). Feed was sampled during each experimental period. Feed refusals were collected 15 min after feeding and stored at $-20^{\circ} \mathrm{C}$ pending analyses.

For determination of the DM content, feed refusals and fresh feces were freeze-dried, feed samples were vacuum-dried at $80^{\circ} \mathrm{C}$, and air-dry feces were dried in a forced-air oven at $103^{\circ} \mathrm{C}$. All samples were dried to a constant weight according to ISO Standard 6496 (ISO, 1998b). Following freeze-drying, feces were ground to pass a 1-mm screen and kept for analyses. Nitrogen content was measured in fresh feed, feed refusals, feces, urine, and aerial $\mathrm{NH}_{3}$ and water that condensed on the heat exchanger according to ISO Standard 5983 (ISO, 1997). Crude fat content was determined after acid hydrolysis in feed and in freeze-dried feces according to ISO Standard 6496 (ISO, 1999). Crude ash content was determined in feed and in freeze-dried feces. Samples were carefully incinerated in a muffle furnace by slowly increasing the temperature from 20 to $550^{\circ} \mathrm{C}$ to prevent foaming, and subsequent incineration took place according to ISO Standard 5984 (ISO, 2002). The lactose content was analyzed enzymatically in feed and in freeze-dried feces (Enzytec; Diffchamb Biocontrol, Nieuwerkerk aan den IJssel, The Netherlands). Gross energy content was analyzed in feed, freeze-dried feces, and urine using adiabatic bomb calorimetry (model C7000 calorimeter; IKA Werke $\mathrm{GmbH}$ \& Co. KG, Staufen, Germany) according to ISO Standard 9831 (ISO, 1998a). All analyses were carried out in duplicate except the nitrogen content in urine, which was determined in triplicate.

\section{Calculations}

For each balance period, intake of ME per chamber was calculated as the difference between digestible energy intake and the sum of urinary energy losses and methane production. From the gaseous exchanges, heat production (HP) was calculated according to the formula of Brouwer (1965). Energy retention was calculated by subtracting HP from ME intake. Retention of nitrogen was calculated from nitrogen in feed and excreta, aerial $\mathrm{NH}_{3}$ and $\mathrm{NH}_{4}{ }^{+}$in water that condensed on the heat exchanger. Energy retained as protein was derived from retained nitrogen, assuming $23.6 \mathrm{~kJ} / \mathrm{g}$ of protein. Energy retention as fat was calculated by subtracting energy retained as protein from ER. For each calf within a balance period, the energy costs per unit of physical activity were estimated by regression of physical activity against heat production, using Equation 1:

$$
\mathrm{HP}_{i j}=\mu+P_{i}+\beta \times X_{j}+e_{i j},
$$

where HP is heat production during posture $i$ and the 6 -min period $j ; \mu$ is the overall mean; $P_{i}$ is the fixed effect of posture $i$ ( $i=$ lying, nonlying); $\beta$ is the regression coefficient of heat production on activity counts; $X_{j}$ is activity counts during the 6 -min period $j$; and $e_{i j}$ is an error term. Posture was included as a fixed effect in Equation 1, because the regression between HP and activity counts appeared to depend on posture, probably related to the distance of the animal to the radar meters. The extra activity costs of nonlying vs. lying were calculated for each calf for each balance period by subtracting the estimated intercept at zero activity of position lying from nonlying $\left(\mathrm{HP}_{n l-1}\right)$, calculated from Equation 1. Subsequently, for each calf within a balance period, $\mathrm{HP}_{\text {act }}$ was calculated as described in Equation 2:

$$
\mathrm{HP}_{\mathrm{act}: j}=\mathrm{HP}_{n l-l}+b_{k} \times X_{j} \text {, }
$$

where $\mathrm{HP}_{\text {act: } j}$ is activity-related heat production during the 6-min period $j ; \mathrm{HP}_{n l-l}$ is the calculated extra activity costs of nonlying vs. lying; $b_{k}$ is the regression coefficient, calculated using Equation 1 during posture $k$; and $X_{j}$ is activity counts during the $6-\min$ period $j$. Balance period and hourly means were calculated for $\mathrm{HP}, \mathrm{HP}_{\mathrm{act}}$, and $\mathrm{HP}_{\text {cor. }}$. By subtracting $\mathrm{HP}_{\text {act }}$ from $\mathrm{HP}$, the heat production not related to physical activity $\left(\mathbf{H P}_{\text {cor }}\right)$ was derived.

\section{Statistical Analysis}

Apparent fecal digestibility and energy and nitrogen balance variables were analyzed for the effects of FF, $\mathrm{FL}$, for the interaction between FF and FL, and for period by ANOVA in 2 ways. First, 3 separate models were used to test 1) the effect of FF within the low FL, 2) the effect of period for FF 1, and 3) the effects of FF and FL for FF 2 and 4 . All 3 models were analyzed with PROC GLM in SAS (SAS Institute, Inc., Cary, NC). Second, the effects of FF, FL, and period were tested in one mixed model, using PROC MIXED in SAS (SAS Institute, Inc.). 
Table 3. Influence of feeding frequency (FF; 1, 2, or 4 meals/d) and feeding level (FL; high vs. low) on mean BW, feed intake, average daily gain, and apparent fecal nutrient digestibility in preruminant calves ${ }^{1}$

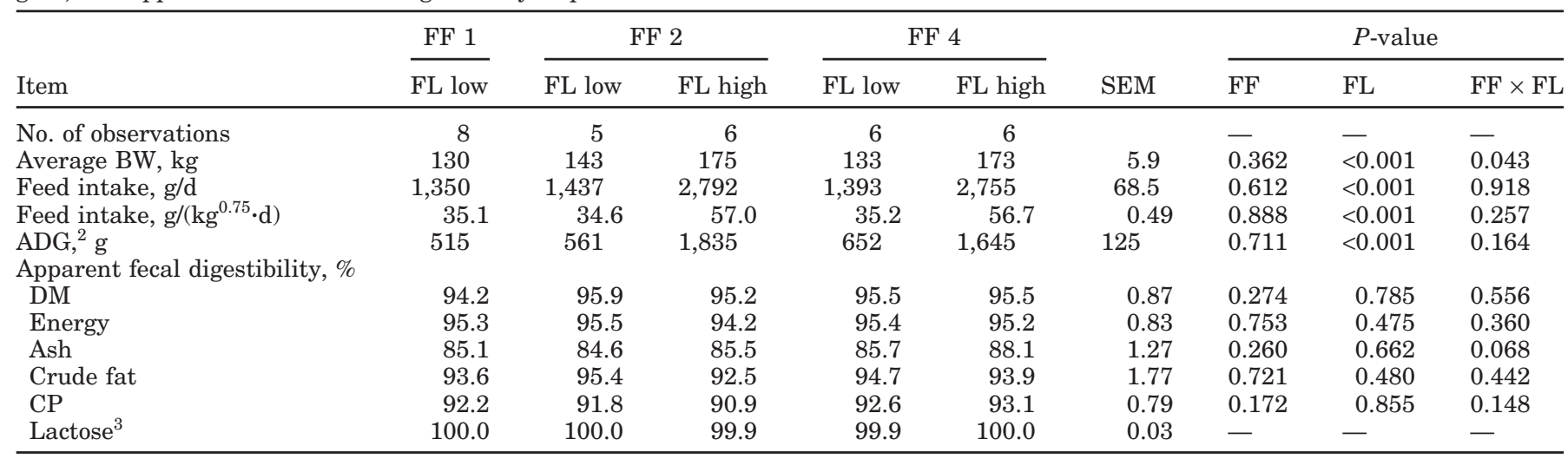

${ }^{1}$ Values are means \pm SEM.

${ }^{2} \mathrm{ADG}=$ Average daily gain.

${ }^{3}$ Errors for lactose digestibility were not normally distributed.

The mixed model included fixed effects of FF, FL, and period, and a random effect of each calf (Eq. 3):

$$
Y_{i j k l}=\mu+\mathrm{FF}_{i}+\mathrm{FL}_{k}+(\mathrm{FF} \times \mathrm{FL})_{i k}+P_{l}+\varepsilon_{i j k l},
$$

where $Y_{i j k l}$ is the dependent variable; $\mu$ is the average intercept; $\mathrm{FF}_{i}$ is the effect of feeding frequency $i(i=1$, $2,4) ; \mathrm{FL}_{k}$ is the effect of feeding level $k(k=1,2) ; P_{l}$ is the effect of period $l(l=1,2)$, and $\varepsilon_{i j k l}$ is an error term, which represents the random effect of calf within feeding frequency $(j=1, \ldots, 6)$. Treatment effects were studied by pairwise comparisons using the Tukey method. The SAS software package version 9.1 (SAS Institute, Inc.) was used in all statistical evaluations.

Because the $P$-values and model predictions of all effects of the 3 models described above were identical to those obtained with the mixed model (Eq. 3), only the results of the mixed model are presented.

\section{RESULTS}

\section{General}

Two animals were excluded from the experiment because of illness and feed refusals. Another calf was excluded from one of the experimental periods. The results were not affected $(P>0.10)$ by the experimental period. Therefore, the effect of the experimental period was not included in the results.

\section{Nutrient Digestibility}

The effects of FL and FF on performance and apparent fecal nutrient digestibility are shown in Table 3. Realized feed intakes were similar to the preplanned intakes.
Also, digestible nutrient intake (data not shown) did not differ $(P>0.10)$ between animals at a similar FL.

The apparent fecal digestibility of DM, energy, protein, and fat exceeded $90 \%$. Treatment effects were not observed. Ash digestibility was about $85 \%$, and an increase of $\mathrm{FF}$ at a high FL tended to raise ash digestibility compared with an increased FF at a low FL $(\mathrm{FF} \times \mathrm{FL}, P<$ $0.10)$. Lactose digestibility was virtually complete at the fecal level.

\section{Energy Partitioning and Protein Utilization}

Data on protein and energy utilization and effects of FL and FF are shown in Table 4.

Feeding Level. Intakes of gross and metabolizable energy were, as expected, markedly higher $(P<0.001)$ at the high FL than at the low FL. Metabolizability of the digestible energy did not differ $(P>0.10)$ between FL. Heat production increased $(P<0.001)$ substantially with FL $\left[146 \mathrm{~kJ} /\left(\mathrm{kg}^{0.75} \cdot \mathrm{d}\right)\right]$, but $\mathrm{HP}_{\text {act }}$ was not affected $(P>0.10)$ by FL. Energy retention (both as protein and as fat) was positively affected $(P<0.001)$ by FL. The efficiency of nitrogen utilization for protein retention, expressed as the percentage of digestible nitrogen intake, was not affected $(P>0.10)$ by FL.

Feeding Frequency. At a similar FL, gross and metabolizable energy intakes did not differ $(P>0.10)$ between FF. Metabolizability of the digestible energy did not differ $(P>0.10)$ between $\mathrm{FF}$ and exceeded $95 \%$ for all treatments. The metabolizability of digestible energy tended to increase when 4 instead of 2 meals were fed at a high FL compared with a low FL $(\mathrm{FF} \times \mathrm{FL}, P<$ $0.10)$. Heat production was not affected by FF, although $\mathrm{HP}_{\text {cor }}$ tended to decrease $(P<0.10)$ with increasing FF. Energy retention, both as protein and as fat, increased 
Table 4. Influence of feeding frequency (FF; 1, 2, or 4 meals/d) and feeding level (FL; high vs. low) on energy and protein balance ${ }^{1}$

\begin{tabular}{|c|c|c|c|c|c|c|c|c|c|}
\hline \multirow[b]{2}{*}{ Item } & \multirow{2}{*}{$\frac{\text { FF } 1}{\text { FL low }}$} & \multicolumn{2}{|c|}{ FF 2} & \multicolumn{2}{|c|}{ FF 4} & \multirow[b]{2}{*}{ SEM } & \multicolumn{3}{|c|}{$P$-value } \\
\hline & & FL low & FL high & FL low & FL high & & $\mathrm{FF}$ & FL & $\mathrm{FF} \times \mathrm{FL}$ \\
\hline Gross energy intake & 754 & 744 & 1,233 & 756 & 1,228 & 10.4 & - & - & - \\
\hline Methane & 2.5 & 3.2 & 4.6 & 4.7 & 5.4 & 0.93 & 0.214 & 0.270 & 0.484 \\
\hline Urinary energy & $30^{c}$ & $27^{\mathrm{c}}$ & $46^{\mathrm{a}}$ & $28^{\mathrm{bc}}$ & $36^{\mathrm{b}}$ & 4.6 & 0.448 & 0.032 & 0.087 \\
\hline ME intake & $683^{\mathrm{b}}$ & $677^{\mathrm{b}}$ & $1,109^{\mathrm{a}}$ & $688^{\mathrm{b}}$ & $1,130^{\mathrm{a}}$ & 13.4 & 0.307 & $<0.001$ & 0.619 \\
\hline $\mathrm{ME}: \mathrm{DE},{ }^{2} \%$ & $95.3^{\mathrm{b}}$ & $95.4^{\mathrm{ab}}$ & $95.6^{\mathrm{ab}}$ & $95.4^{\mathrm{ab}}$ & $96.5^{\mathrm{a}}$ & 0.42 & 0.518 & 0.227 & 0.089 \\
\hline Activity-related & 70 & 75 & 75 & 65 & 69 & 10.8 & 0.768 & 0.873 & 0.805 \\
\hline Resting & $480^{\mathrm{b}}$ & $483^{b}$ & $626^{\mathrm{a}}$ & $463^{\mathrm{b}}$ & $607^{\mathrm{a}}$ & 9.1 & 0.055 & $<0.001$ & 0.957 \\
\hline \multicolumn{10}{|l|}{ Energy retention } \\
\hline Total & $133^{\mathrm{cd}}$ & $119^{\mathrm{d}}$ & $408^{\mathrm{b}}$ & $159^{\mathrm{c}}$ & $453^{\mathrm{a}}$ & 15.2 & $<0.001$ & $<0.001$ & 0.812 \\
\hline As protein & $74^{\mathrm{c}}$ & $75^{\mathrm{c}}$ & $120^{\mathrm{b}}$ & $81^{\mathrm{c}}$ & $136^{\mathrm{a}}$ & 4.7 & $<0.001$ & $<0.001$ & 0.153 \\
\hline As fat & $59^{\mathrm{bc}}$ & $45^{\mathrm{c}}$ & $288^{\mathrm{a}}$ & $79^{b}$ & $317^{\mathrm{a}}$ & 14.1 & $<0.001$ & $<0.001$ & 0.809 \\
\hline \multicolumn{10}{|l|}{ Nitrogen retention } \\
\hline
\end{tabular}

${ }^{\mathrm{a}-\mathrm{d}}$ Within a row, means with different superscripts differ $(P<0.05)$.

${ }^{1}$ Values are means $\pm \mathrm{SEM}$ and expressed in $\mathrm{kJ} /\left(\mathrm{kg}^{0.75} \cdot \mathrm{d}\right)$ unless otherwise specified.

${ }^{2} \mathrm{ME}: \mathrm{DE}=\mathrm{ME}$ intake/digestible energy intake $\times 100$.

${ }^{3} \mathrm{dN}$ intake $=$ Digestible nitrogen intake.

$(P<0.001)$ with increasing FF. The efficiency of nitrogen utilization for protein retention, expressed either as the percentage of dietary nitrogen (data not shown) or as the percentage of digested nitrogen, increased $11 \%(P<$ 0.05 ), from $49.1 \%$ at FF 2 to $54.4 \%$ at FF 4 at the high FL.

\section{Circadian Rhythms}

Circadian rhythms of $\mathrm{HP}$ and $\mathrm{HP}_{\text {cor }}$ are shown in Figure 1. Consistently, meal ingestion was followed by an $\mathrm{HP}$ peak (Figures 1a, 1c). When corrected for $\mathrm{HP}_{\mathrm{act}}$, whose circadian rhythm did not differ between treatments, a regular pattern of $\mathrm{HP}_{\text {cor }}$ was observed (Figures $1 b, 1 d)$.

Feeding Level. An increased FL increased the minimal HP [+111 and $\left.+97 \mathrm{~kJ} /\left(\mathrm{kg}^{0.75} \cdot \mathrm{d}\right)\right]$ and $\mathrm{HP}_{\text {cor }}[+90$ and $\left.+92 \mathrm{~kJ} /\left(\mathrm{kg}^{0.75} \cdot \mathrm{d}\right)\right]$ for FF 2 and 4, respectively. At a higher $\mathrm{FL}$, the amplitude of $\mathrm{HP}_{\text {cor }}$ increased by 63 and $100 \%$ for FF 2 and 4, respectively. For both FF, a higher FL resulted in a delay of the $\mathrm{HP}_{\text {cor }}$ peaks.

Feeding Frequency. Although daily HP was not affected by FF (Table 4), the circadian rhythm of HP clearly differed between FF (Figures 1a, 1c). The minimal HP and $\mathrm{HP}_{\text {cor }}$ decreased with decreasing $\mathrm{FF}$. The amplitude of $\mathrm{HP}$ and $\mathrm{HP}_{\text {cor }}$ increased with decreasing FF. Furthermore, the increase of the amplitude for $\mathrm{H}_{\text {cor }}$ with decreasing $\mathrm{FF}$ was greater at a high FL $\left[+100 \mathrm{~kJ} /\left(\mathrm{kg}^{0.75} \cdot \mathrm{d}\right)\right]$ than at a low FL $\left[+72 \mathrm{~kJ} /\left(\mathrm{kg}^{0.75} \cdot \mathrm{d}\right)\right]$. A decreased FF delayed the time of the maximal $\mathrm{H}_{\text {cor }}$. Following a meal at a low $\mathrm{FL}$, for example, the maximal $\mathrm{H}_{\text {cor }}$ was reached after 6 $\mathrm{h}$ for FF 1 and after about $1 \mathrm{~h}$ for FF 4 .

\section{DISCUSSION}

This study was conducted to assess the effects of FF (i.e., 1,2 , or 4 meals/d) at $2 \mathrm{FL}\left(1.5 \times\right.$ or $\left.2.5 \times \mathrm{ME}_{\mathrm{m}}\right)$ on apparent fecal digestibility and energy and protein metabolism in heavy preruminant calves. In the $4 \mathrm{wk}$ prior to the start of the study, calves were well adapted to the experimental treatment. Feeding level was confounded with experimental period in this study. The effect of period could be tested only for calves fed once daily, and an effect appeared to be absent. However, an interaction between FL and period could not be excluded for calves at FF 2 and 4. Our main interest was in examining the effects of $\mathrm{FF}$ on nutrient utilization when a quickly hydrolyzable protein source (i.e., whey protein) was used.

\section{Nutrient Digestibility}

Apparent fecal digestibility was generally high and comparable to values in other studies (Donnelly and Hutton, 1976; Gerrits et al., 1996; Diaz et al., 2001). Nutrient digestibility was not affected by FL or FF. The lack of effect of FL is in accordance with findings in milk-fed calves of $60 \mathrm{~kg}$ BW (Donnelly and Hutton, 1976). In pigs, an increased FL resulted in a higher rate of passage of digesta, which may cause a reduction in nutrient digestibility (Roth and Kirchgessner, 1985). The analogy between a higher FL and a decreased FF (i.e., an increased meal size) may indicate that similar mechanisms are involved. Indeed, distribution of the daily milk supply over 2 (Ternouth et al., 1977), 2 or 4 (Keusenhoff and 

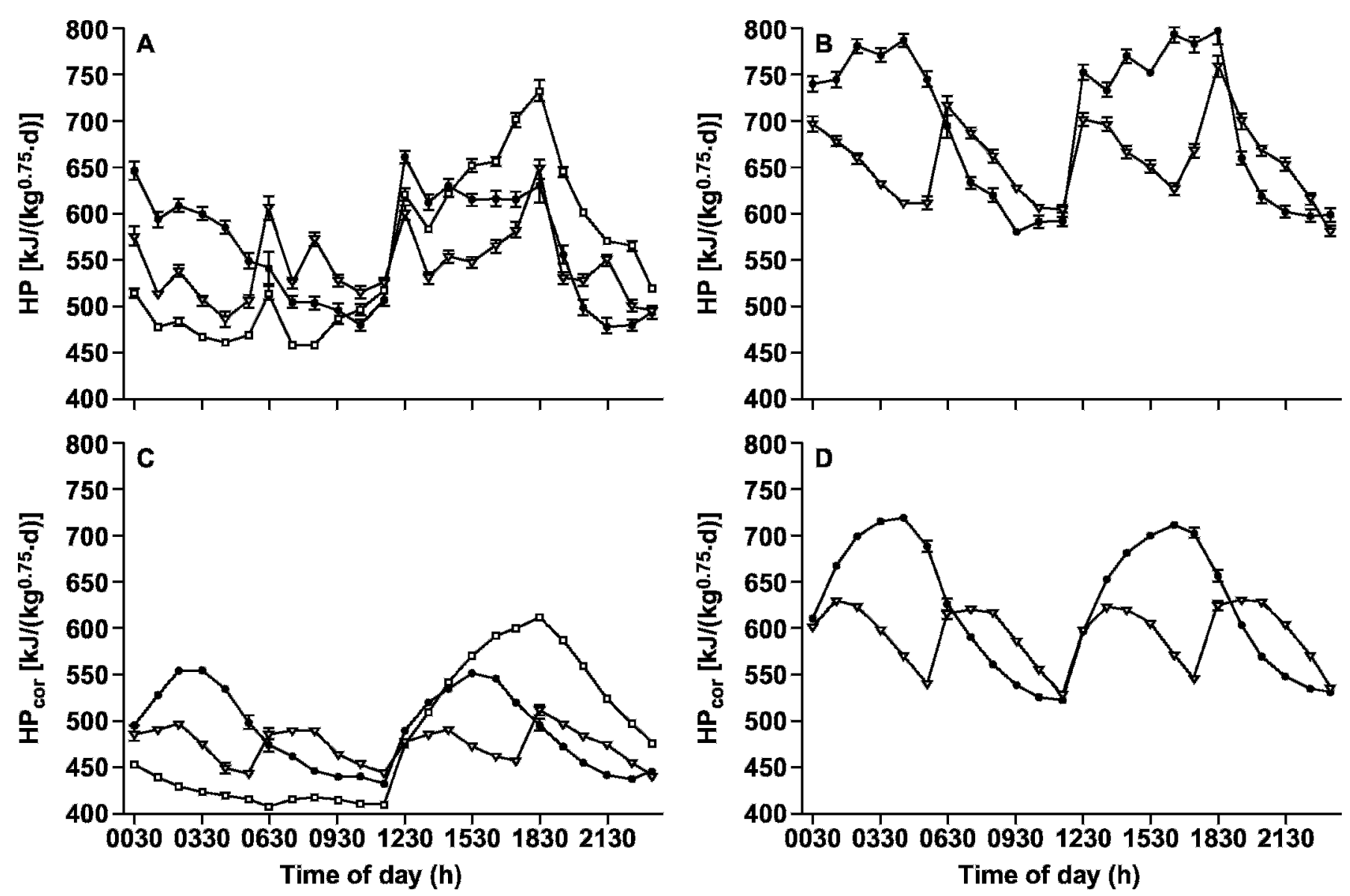

Figure 1. Influence of feeding frequency (FF) $1(\square), 2(\bullet)$, and $4(\nabla)$ at a low (A and C) and a high (B and D) feeding level (FL) on the circadian patterns of heat production (HP; A and B) and HP corrected for activity ( $\mathrm{HP}_{\text {cor }}$; C and D) in heavy preruminant calves. Values are means \pm SEM, $\mathrm{n}=8(\square), \mathrm{n}=5\left(\bullet\right.$, in A and C), $\mathrm{n}=6\left(\bullet\right.$, in B and D), or $\mathrm{n}=6(\nabla)$. The low FL was $690 \mathrm{~kJ} \mathrm{ME} /\left(\mathrm{kg}{ }^{0.75} \cdot \mathrm{d}\right)$ and the high FL was $1150 \mathrm{~kJ} \mathrm{ME} /\left(\mathrm{kg}^{0.75} \cdot \mathrm{d}\right.$ ). Feeding times were 0000 (FF 2 and 4), 0600 (FF 4), 1200 (FF 1, 2, and 4), and $1800 \mathrm{~h}$ (FF 4).

Piatkowski, 1983), or 6 meals (J. Huisman, unpublished data) instead of 1 meal increased the rate of gastric emptying substantially, but did not affect apparent fecal nutrient digestibility in preruminant calves (Keusenhoff and Piatkowski, 1983). The effect of rate of passage can be expected to be more pronounced when slowly digestible and less-digestible feed ingredients are used. In the study of Williams et al. (1986), for example, apparent fat digestibility was very low (only 67\%) for calves fed once daily and increased to $85 \%$ for animals fed 6 meals per day.

\section{Energy Partitioning and Protein Utilization}

Feeding Level. Metabolizability of the digestible energy was on average $95.6 \%$, which corresponds with other values found in preruminant calves (Gerrits et al., 1996; Diaz et al., 2001), whereas the metabolizability can be markedly lower in very young, unadapted calves (76\%; Schrama et al., 1992). Activity-related heat pro- duction was unaffected by FL in this study, whereas a higher FL was reported to decrease physical activity in pigs (Terlouw and Lawrence, 1993). As a percentage of $\mathrm{HP}, \mathrm{HP}_{\text {act }}$ was numerically higher $(P=0.159)$ at a low FL (12.9\%) than at a high FL (10.5\%).

An increased FL resulted in a higher ER and also in a higher efficiency of utilization of ME for ER. This efficiency increased from $18-23 \%$ at a low FL to $36-40 \%$ at a high FL because of a decreased contribution of $\mathrm{ME}_{\mathrm{m}}$ to the total energy expenditure. The marginal efficiency of utilization of $\mathrm{ME}$ (i.e., excluding $\mathrm{ME}_{\mathrm{m}}$ ) could be calculated by regression of $\mathrm{ER}$ on the intake of $\mathrm{ME}$ for animals fed at both FL. The marginal efficiency was $72 \%$ and did not differ between animals fed 2 and 4 meals daily. Similar efficiencies, 68, 69, and 69\%, respectively, were reported in calves up to $150 \mathrm{~kg}$ of BW (Van Es et al., 1967; Van Es, 1970; Meulenbroeks et al., 1986). Gerrits et al. (1996) found a slightly lower marginal efficiency of utilization of ME for ER (on average 60\%) in calves of 80 to $160 \mathrm{~kg}$ of BW but a similar efficiency (on average 
$71 \%$ ) in calves of 160 to $240 \mathrm{~kg}$ of BW. The higher efficiency of utilization for heavy animals in their study coincided with lower estimates of $\mathrm{ME}_{\mathrm{m}}$.

The efficiency with which digestible protein was utilized was not affected by FL in this study. Dilution of the protein requirements for maintenance and independent additional effects of increased energy and protein intake on protein deposition (Gerrits et al., 1996) could be expected to result in a higher efficiency of utilization of digestible protein for growth. On the other hand, increased temporal AA availability at a high FL may have exceeded the capacity for protein retention and possibly resulted in increased AA oxidation. The lack of effect of FL on protein utilization is in agreement with previous studies in milk-fed calves (Meulenbroeks et al., 1986) and growing pigs (Bikker, 1994), but not with the study of Gerrits et al. (1996) in calves.

Feeding Frequency. Altogether, the numerically increased ME intake and decreased HP with increasing FF resulted in a significantly increased ER, both as protein and as fat. The realized ME intake did not differ between FF at the same FL and amounted to $1.48 \times$ and $2.43 \times$ the $\mathrm{ME}_{\mathrm{m}}$ for the low and high FL, respectively. At both FL, HP was not affected by FF, but calves fed twice daily produced numerically slightly more heat than those fed 1 or 4 times daily ( +1 and $+5 \%$, respectively) at a low FL.

The increased fat deposition in frequently fed calves contrasts with studies in humans and monogastric animals in which eating more frequently either decreased (especially in epidemiological observations) or did not affect body adiposity (Dawson, 1999; Bellisle, 2004). The increased energy expenditure for gastrointestinal tissues may partly explain the lower fat deposition when calves were fed less frequently. Early studies have shown that feeding animals less frequently can result in increased weights of the gastrointestinal tissues (Allee et al., 1972, for pigs; Pocknee and Heaton, 1976, for rats) to cope with large meal sizes. Also, Walker et al. (1967) showed that the weight of the abomasum increased $41 \%$ when lambs were fed a similar amount of cow's milk in 2 instead of in 6 meals. Gastrointestinal hypertrophy with decreasing FF contributes to increased energy requirements, because portal-drained viscera account for a disproportionately large amount of HP. Although they represent only $6 \%$ of total BW in milk-fed calves, these tissues are responsible for $17 \%$ of HP, and even for 33 to $54 \%$ of the postprandial increase of HP (Ortigues et al., 1995). An improved synchrony between energy supply and energy requirements may also have increased ER at a higher FF. Finally, an improved endocrine profile could have limited energy losses with increasing FF in the present study. Several studies (e.g., Doppenberg and Palmquist, 1991; Hostettler-Allen et al., 1994) indicate that the capability of milk-fed calves to process large amounts of nutrients is limited, which can result in characteristic metabolic and endocrine changes related to hyperglycemia and insulin resistance. Feeding the daily milk supply in more than 5 meals avoided hyperglycemia and resulted in an endocrine pattern that was potentially more favorable for anabolism (Kaufhold et al., 2000).

There was no effect of FF on physical activity, although feeding calves more frequently was anticipated to result in an increased $\mathrm{HP}_{\mathrm{act}}$. Also, when expressed as a percentage of $\mathrm{HP}, \mathrm{HP}_{\text {act }}$ was not affected $(P>0.10)$ by FF. The absence of an effect on physical activity could be due to the individual housing of animals, which has been shown to reduce activity in milk-fed calves (Veissier et al., 1998). Furthermore, the cephalic phase may have induced relatively more physical activity in the more frequently fed calves, because certain intensive behaviors (e.g., manipulation and licking objects) were frequently observed during the preprandial period (J. J. G. C. Van den Borne, S. J. F. M. van der Heijden, E. A. M. Bokkers, J. E. Bolhuis, and W. J. J. Gerrits, unpublished data). Calves at FF 4 experienced the preprandial period 4 times a day instead of once daily for calves at FF 1 . Similarly, LeBlanc and Diamond (1986) found in dogs that the amplitude of HP for 4 small meals $(125 \mathrm{~g})$ was twice as large as that for 1 large meal $(500 \mathrm{~g})$. They ascribed this effect to the heat produced during the cephalic phase for each meal. In dogs, heat production for a single meal was comparable to feeding 4 meals when the meal was preceded by 3 simulated meals (sham feeding), which suggests that sensory stimulation may interfere with the results. In the present study, calves could not see, smell, or hear the milk preparation. The fixed feeding pattern and long adaptation period, however, may have enabled them to anticipate the times of feeding. Finally, the provision of water and entrance into the respiration chambers to collect samples twice daily may have stimulated physical activity in the calves at FF 1.

Increasing $\mathrm{FF}$ resulted in a more efficient utilization of digestible protein for protein gain. The relative increase in efficiency was $10.3 \%$ when the $\mathrm{FF}$ increased from 1 to 4 at a low FL and 11.0\% when the FF increased from 2 to 4 at a high FL. We speculated that AA availability was temporarily less abundant at a higher FF, which may avoid temporal AA excesses and a concomitant increase in AA oxidation. Measurement of AA oxidation could provide further insight into the underlying mechanism that results in increased AA utilization in calves. The effects of FF on protein utilization in human and rat studies are inconsistent (as reviewed by Dawson, 1999), and the results from FF experiments in pigs are also confusing (e.g., Partridge et al., 1985; Mroz et al., 1994). The effects of FF may depend on the kinetics of 
protein digestion and absorption. In pigs, for example, AA oxidation decreased with increasing $\mathrm{FF}$ when synthetic lysine was included in the diet, but it was not affected by FF when protein-bound lysine was used (Batterham and Bayley, 1989). This may explain why protein retention in (heavy) calves was affected by $\mathrm{FF}$ in the present study when whey protein was used, but not in (young) calves when skimmed milk protein was fed (Williams et al., 1986).

We hypothesized that the increase in protein utilization with FF would be more pronounced at a higher FL. However, there was no significant interaction between $\mathrm{FL}$ and FF $(P=0.315)$, although protein utilization increased by $4.9 \%$ at a low FL and by $11.0 \%$ at a high FL when the FF was increased from 2 to 4 meals daily.

Marginal efficiencies of protein utilization were calculated for animals fed at both FL. The marginal efficiency for calves at FF $2(48.3 \%)$ was numerically, but not statistically $(P=0.12)$, lower than for calves at FF $4(56.3 \%)$. Both values are considerably higher than the values previously found in heavy preruminant calves (between 25 and 30\%; Gerrits et al., 1996). The different protein sources (whey vs. skimmed milk) may have contributed to the increased marginal efficiency in the present study.

\section{Circadian Rhythms}

Surprisingly, the considerable differences in circadian fluctuations of HP did not result in a different HP for the $3 \mathrm{FF}$. The circadian rhythm of HP can be compared with the results in young calves of $60 \mathrm{~kg}$ of BW (Ortigues et al., 1995). Those researchers fed calves twice daily within an 8-h interval at a FL of $2.3 \times \mathrm{ME}_{\mathrm{m}}$. The amplitude of HP could be expected to be higher in their study than in the present study, based on the dissimilar inter$\operatorname{val}(8 \mathrm{~h})$ between the 2 meals in their study. Nonetheless, the amplitude was slightly lower in the study of Ortigues et al. $\left[1995 ; 171 \mathrm{~kJ} /\left(\mathrm{kg}^{0.75} \cdot \mathrm{d}\right)\right]$ than in the present study at FF 2 and a high FL $\left[198 \mathrm{~kJ} /\left(\mathrm{kg}^{0.75} \cdot \mathrm{d}\right)\right]$, although the minimal HP was substantially lower $\left[91 \mathrm{~kJ} /\left(\mathrm{kg}^{0.75} \cdot \mathrm{d}\right)\right]$ in their study. The difference can be explained by the difference in FL and by assuming an inefficiency of energy utilization of $28 \%$ (as found in this study). Also, the use of skimmed milk powder in the study of Ortigues et al. (1995) may have caused a slow absorption of fatty acids and AA and consequently leveled off the HP peaks. The different protein source could also explain the 70\% higher amplitude for $\mathrm{HP}_{\text {cor }}$ in calves of $175 \mathrm{~kg}$ of $\mathrm{BW}$ $\left[189 \mathrm{~kJ} /\left(\mathrm{kg}^{0.75} \cdot \mathrm{d}\right)\right]$ than in calves of $60 \mathrm{~kg}$ of BW [112 kJ/ $\left.\left(\mathrm{kg}^{0.75} \cdot \mathrm{d}\right)\right]$. Finally, the interval until maximum HP was more than $4 \mathrm{~h}$ for calves of $175 \mathrm{~kg}$ of BW in the present study, whereas calves of $60 \mathrm{~kg}$ of BW (Ortigues et al., 1995) reached maximum HP within 1 to $2 \mathrm{~h}$ postprandial. This discrepancy could result from the use of a clotting protein source in the study of Ortigues et al. (1995), but may also indicate the previously mentioned insensitivity to insulin and the metabolic difficulties of heavy milk-fed calves in handling glucose.

\section{CONCLUSIONS}

This experiment showed that increasing the frequency of feeding a rapidly hydrolyzable protein source (i.e., whey) increased the efficiency with which protein was utilized by heavy preruminant calves. Feeding 4 instead of 2 daily meals at a high FL increased the efficiency of digestible protein utilization by $11 \%$, from 49.1 to $54.5 \%$, respectively. The hypothesis that the efficiency of protein utilization would be affected more by FF at a high than at a low FL was not confirmed. Fat deposition increased with increasing FF. As expected, an increased FL resulted in an increased fat deposition $\left[+245 \mathrm{~kJ} /\left(\mathrm{kg}^{0.75} \cdot \mathrm{d}\right)\right]$ and a higher efficiency of energy utilization $(+18 \%)$. We concluded that the nutrient utilization of heavy preruminant calves increases with increasing FF of a rapidly hydrolyzable protein source. This can be relevant to calf nutrition, because skimmed milk protein has generally been replaced by whey and vegetable protein sources in calf milk replacers.

\section{ACKNOWLEDGMENTS}

The authors thank M. J. W. Heetkamp, S. J. F. M. van der Heijden, J. M. van der Linden, T. Zandstra, and the personnel of the experimental farm De Haar for their technical assistance. The financial support of the Technology Foundation STW (the applied science division of NWO and the technology program of the Ministry of Economic Affairs; Utrecht, The Netherlands), the Product Board Animal Feed (Den Haag, The Netherlands), and Orffa Nederland Feed BV (Giessen, The Netherlands) is gratefully acknowledged.

\section{REFERENCES}

Allee, G. L., D. R. Romsos, G. A. Leveille, and D. H. Baker. 1972. Metabolic adaptation induced by meal-eating in the pig. J. Nutr. 102:1115-1122.

Batterham, E. S., and H. S. Bayley. 1989. Effect of frequency of feeding of diets containing free or protein-bound lysine on the oxidation of $\left[{ }^{14} \mathrm{C}\right]$ lysine or $\left[{ }^{14} \mathrm{C}\right]$ phenylalanine by growing pigs. Br. J. Nutr. 62:647-655.

Bellisle, F. 2004. Impact of the daily meal pattern on energy balance. Scand. J. Nutr. 48:114-118.

Bikker, P. 1994. Protein and lipid accretion in body components of growing pigs. Ph.D. thesis, Wageningen Agricultural University, Wageningen, The Netherlands.

Blome, R. M., J. K. Drackley, F. K. McKeith, M. F. Hutjens, and G. C. McCoy. 2003. Growth, nutrient utilization, and body composition of dairy calves fed milk replacers containing different amounts of protein. J. Anim. Sci. 81:1641-1655.

Brouwer, E. 1965. Report of sub-committee on constants and factors. Pages 441-443 in Energy Metabolism. K. L. Blaxter, ed. Academic Press, London, UK. 
Dawson, J. M. 1999. Variation in nutrient supply and effects on whole body anabolism. Pages 101-126 in Protein Metabolism and Nutrition. Eur. Assoc. Animal Prod. Publication No. 96. G. E. Lobley, A. White, and J. C. MacRae, ed. Wageningen Press, Wageningen, The Netherlands.

Diaz, M. C., M. E. Van Amburgh, J. M. Smith, J. M. Kelsey, and E. L. Hutten. 2001. Composition of growth of Holstein calves fed milk replacer from birth to 105-kilogram body weight. J. Dairy Sci. 84:830-842.

Donnelly, P. E., and J. B. Hutton. 1976. Effects of dietary protein and energy on the growth of Friesian bull calves, I. Food intake, growth, and protein requirements. N. Z. J. Agric. Res. 19:289-297.

Doppenberg, J., and D. L. Palmquist. 1991. Effect of dietary fat level on feed intake, growth, plasma metabolites and hormones of calves fed dry or liquid diets. Livest. Prod. Sci. 29:151-158.

Gerrits, W. J. J., G. H. Tolman, J. W. Schrama, S. Tamminga, M. W. Bosch, and M. W. A. Verstegen. 1996. Effect of protein and proteinfree energy intake on protein and fat deposition rates in preruminant calves of 80 to $240 \mathrm{~kg}$ live weight. J. Anim. Sci. 74:2129-2139.

Hostettler-Allen, R. L., L. Tappy, and J. W. Blum. 1994. Insulin resistance, hyperglycemia, and glucosuria in intensively milk-fed calves. J. Anim. Sci. 75:160-173.

ISO. 1997. Animal feeding stuffs. Determination of nitrogen content and calculation of crude protein content. Kjeldahl method. ISO 5983. International Organization for Standardization, Geneva, Switzerland.

ISO. 1998a. Animal feeding stuffs, animal products, and faeces or urine. Determination of gross calorific value. ISO 9831. International Organization for Standardization, Geneva, Switzerland.

ISO. 1998b. Animal feeding stuffs. Determination of moisture and other volatile matter content. ISO 6496. International Organization for Standardization, Geneva, Switzerland.

ISO. 1999. Animal feeding stuffs. Determination of fat content. ISO 6496. International Organization for Standardization, Geneva, Switzerland.

ISO. 2002. Animal feeding stuffs. Determination of crude ash. ISO 5984. International Organization for Standardization, Geneva, Switzerland.

Kaufhold, J. N., H. M. Hammon, R. M. Bruckmaier, B. H. Breier, and J. W. Blum. 2000. Postprandial metabolism and endocrine status in veal calves fed at different fequencies. J. Dairy Sci. 83:2480-2490.

Keusenhoff, R., and B. Piatkowski. 1983. Der Einfluß verschiedener Tränkfrequenzen und Milchbehandlungen auf den Digestafluß am Duodenum des Kalbes. Arch. Tierernahr. 33:179-187.

LeBlanc, J., and P. Diamond. 1986. Effect of meal size and frequency on postprandial thermogenesis in dogs. Am. J. Physiol. 250:E144-E147.

Meulenbroeks, J., M. W. A. Verstegen, W. Van der Hel, S. Korver, and G. Kleinhout. 1986. The effect of genotype and metabolizable energy intake on protein and fat gain in veal calves. Anim. Prod. 43:195-200.

Mroz, Z., A. W. Jongbloed, and P. A. Kemme. 1994. Apparent digestibility and retention of nutrients bound to phytate complexes as influenced by microbial phytase and feeding regimen in pigs. J. Anim. Sci. 72:126-132.

Ortigues, I., C. Martin, D. Durand, and M. Vermorel. 1995. Circadian changes in energy expenditure in the preruminant calf: Whole animal and tissue level. J. Anim. Sci. 73:552-564.

Partridge, I. G., A. G. Low, and H. D. Keal. 1985. A note on the effect of feeding frequency on nitrogen use in growing boars given diets with varying levels of free lysine. Anim. Prod. 40:375-377.
Pocknee, R. C., and F. W. Heaton. 1976. The effect of feeding frequency on the growth and composition of individual organs in the rat. Br. J. Nutr. 35:97-104.

Roth, F. X., and M. Kirchgessner. 1985. Verdaulichkeit und intestinale Passagerate beim Schwein in Abhängigkeit vam Fütterungsniveau und Rohfasergehalt des Futters. J. Anim. Physiol. Anim. Nutr. (Berl.) 53:254-264.

Schrama, J. W., W. Van der Hel, A. Arieli, and M. W. A. Verstegen. 1992. Alteration of energy metabolism of calves fed below maintenance during 6 to 14 days of age. J. Anim. Sci. 70:2527-2532.

Schroeder, G. F., E. C. Titgemeyer, M. S. Awawdeh, and D. P. Gnad. 2004. Effects of energy supply on methionine utilization by growing steers. J. Dairy Sci. 87(Suppl. 1):115. (Abstr.)

Terlouw, E. M. C., and A. B. Lawrence. 1993. Long-term effects of food allowance and housing on development of stereotypies in pigs. Appl. Anim. Behav. Sci. 38:103-126.

Ternouth, J. H., J. H. B. Roy, I. J. F. Stobo, S. M. Shotton, and C. M. Gillies. 1977. Concurrent studies of the flow of digesta in the duodenum and of exocrine pancreatic secretion in calves, 5 . The effect of giving milk once and twice daily, and of weaning. Br. J. Nutr. 37:237-249.

Titgemeyer, E. C. 2003. Amino acid utilization by growing and finishing ruminants. Pages 329-346 in Amino Acids in Animal Nutrition. 2nd ed. J. P. F. D'Mello, ed. CAB International, Wallingford, UK.

Van Es, A. J. H. 1970. Simulation of the growth of veal calves fed liquid milk replacers. Pages 97-100 in Energy Metabolism of Farm Animals. Eur. Assoc. Animal Prod. Publication No. 13. A. Schürch and C. Wenk, ed. Juris Druck Verlag, Zürich, Switzerland.

Van Es, A. J. H., H. J. Nijkamp, E. J. Van Weerden, and K. K. Van Hellemond. 1967. Energy, carbon and nitrogen balance experiments with veal calves. Pages 197-201 in Energy Metabolism of Farm Animals, K. L. Blaxter, J. Kielanowski, and G. Thorbek, ed. Oriel Press, Newcastle upon Tyne, UK.

Veissier, I., A. R. Ramirez de la Fe, and P. Pradel. 1998. Nonnutritive oral activities and stress responses of veal calves in relation to feeding and housing conditions. Appl. Anim. Behav. Sci. 57:35-49.

Verdonk, J. M. A. J., W. J. J. Gerrits, G. M. Beelen, and A. J. M. Jansman. 1999. Effect of protein source on portal nutrient fluxes in pre-ruminant calves. Page 47 (Abstr.) in Protein Metabolism and Nutrition. Eur. Assoc. Animal Prod. Publication No. 96. G. E. Lobley, A. White, and J. C. MacRae, ed. Wageningen Press, Wageningen, The Netherlands.

Verstegen, M. W. A., W. Van der Hel, H. Brandsma, A. M. Henken, and A. M. Bransen. 1987. The Wageningen respiration unit for animal production research: A description of the equipment and its possibilities. Pages 21-48 in Energy Metabolism in Farm Animals: Effects of Housing, Stress and Disease. M. W. A. Verstegen and A. M. Henken, ed. Martinus Nijhoff Publishers, Dordrecht, The Netherlands.

Walker, D. M., L. J. Cook, and K. T. Jagusch. 1967. Nitrogen balance studies with the milk-fed lamb. 5. Effect of frequency of feeding. Br. J. Nutr. 21:275-287.

Wenk, C., and A. J. H. Van Es. 1976. Eine Methode zur Bestimmung des Energieauswandes für die körperlich Aktivität von wachsenden Küken. Schweiz. Landwirtsch. Monatsh. 54:232.

Williams, P. E. V., R. J. Fallon, J. M. Brockway, G. M. Innes, and A. C. Brewer. 1986. The effect of frequency of feeding milk replacer to pre-ruminant calves on respiratory quotient and the efficiency of food utilization. Anim. Prod. 43:367-375. 